\title{
Cellulase Activities of Bacteria in Liquid and Solid Phases of the Rumen Digesta of Buffaloes and Cattle
}

\section{Hideya Номма}

\author{
Institute of Agriculture and Forestry, University of \\ Tsukuba, Sakura-mura, Ibaraki-ken 305
}

(Received September 27, 1985)

\begin{abstract}
Rumen bacteria of buffaloes and cattle, of which the former have been previously found to be consistently higher in concentration of bacteria than the latter, were separated from the solid (solid-associated bacteria; $\mathrm{SAB}$ ) and the liquid (liquid-associated bacteria; LAB) fractions of digesta by differential centrifugation ( 600 and $20,000 \times \mathrm{g}$ ). Concentration of bacteria and cellulase activity in each fraction in buffaloes were compared with those in cattle to clarify the effects of bacterial concentration on cellulose digestion in the rumen. Three pairs of each species were fed only with one of three roughages (in increasing order of quality; rice straw, timothy hay and alfalfa hay cubes) for 14 days. The same procedure was repeated exchanging the roughage for the other one being different in quality rotationally. Carboxymethyl cellulose was used as substrate for cellulase activity and 2,6-diaminopimelic acid (DAP) as an indicator for bacterial matter. Concentration of DAP in SAB was higher in buffaloes than in cattle but cellulase activity was not significantly different between the species. Consequently, specific activity (cellulase activity/DAP) in SAB was significantly lower in buffaloes than in cattle. These results suggest that a higher bacterial concentration promotes attachment of bacteria to plant particles but the association of cellulolytic bacteria is not necessarily increased under this condition. Concentration of DAP, cellulase activity and specific activity in LAB in buffaloes remained high whichever roughage they were fed, whereas those in cattle in increased with quality of roughage. $S A B$ in both species were lower in concentration of DAP but higher in cellulase activity and specific activity than LAB, indicating consistently higher celluloytic activity than LAB.
\end{abstract}

Jpn. J. Zootech. Sci., 57 (4): 336-341, 1986

Key words: rumen bacteria, solid and liquid phases, cellulase activity, buffaloes and cattle

Several experiments have shown that buffaloes utilize low quality feeds better than cattle ${ }^{1-8)}$, presumably because buffaloes have more ruminal microbes. A higher concentration of microbes in the rumen may promote their association with plant particles, and this would be essential for degradation of structual polysaccarides such as cellulose. However, little is known about the activity of microbes associated with plant particles in the rumen, although considerable amounts of microorganisms adhere to plant materials ${ }^{6,7)}$. In the present paper, the concentration of bacteria and their cellulase activity in liquid and solid phases of the rumen digesta of buffaloes were compared with those of cattle to clarify the effects of microbial concentration on cellulose digestibility in the rumen. Cellulolytic activity of bacteria in the two phases was 
also compared.

\section{Materials and Methods}

Three swamp buffaloes and three Holstein cattle cows of average body weights of 487 and $523 \mathrm{~kg}$ were divided into three pairs of each species. Each pair was fed only with one of three roughages (alfalfa hay cubes, timothy hay and rice straw), for a 14 day-experimental period which consisted of a 12 day-adaptation period followed by a 2 day-collection of the rumen digesta. The same procedure was repeated exchanging the roughage for the other one rotationally. Animals were fed sufficient quantity three times daily (at 10:00, 15:00, and 19:00) to effect about a $10 \%$ refusal. Trace-mineralized salt blocks were provided ad libitum, as was water, except as noted below. After water was removed an hour before (9:00) morning feeding, about $1.5 \mathrm{l}$ of the rumen digesta were taken at 0,2 and $4 \mathrm{~h}$ postfeeding with a rumen catheter, and then water was provided again.

The sample of the rumen digesta $(200 \mathrm{ml})$ was immediately centrifuged at $600 \times \mathrm{g}$ for $5 \mathrm{~min}$; mixed bacteria in the liquid phase were defined as liquid-associated bacteria ( $\mathrm{LAB}$ ), and those in the solid phase as solid-associated bacteria (SAB). Half amounts of the liquid fraction $(100 \mathrm{ml})$ were further centrifuged at $20,000 \times \mathrm{g}$ for 30 min and the precipitates were resuspended in $50 \mathrm{ml}$ of $20 \mathrm{mM}$ sodium phosphate buffer $(\mathrm{pH} 7.0)$. After ultrasonication at $4^{\circ} \mathrm{C}$ for $15 \mathrm{~min}$, the suspension was stored at $-25^{\circ} \mathrm{C}$ under $\mathrm{N}_{2}$ gas until they were analysed for enzyme activity and concentration of LAB. The solid fraction collected from $200 \mathrm{ml}$ of the original rumen sample was also resuspended in $50 \mathrm{~m} l$ of the same buffer described above. After ultrasonication at $4^{\circ} \mathrm{C}$ for $15 \mathrm{~min}$, the suspension was strained through four layers of surgical gauze and the plant particles remaining were washed with another $50 \mathrm{ml}$ of the same buffer, The strained liquor and the washings were mixed and stored at $-25^{\circ} \mathrm{C}$ under $\mathrm{N}_{2}$ gas as the suspension of SAB fraction.

Cellulase activity and bacterial concentration in the two fractions were measured as previously reported ${ }^{4}$. Carboxymethyl cellulose was used as a substrate and 2,6diaminopimelic acid (DAP) as an indicator of bacterial matter. Specific activity of the enzyme was expressed as cellulase activity/DAP4). Analysis of nutrients in roughages was performed according to methods of A.O.A. $\mathrm{C}^{8}$.

The experimental data on each bacterial fraction were subjected to a 2 (species) $\times 3$ (feeds) $\times 3$ (sampling times) factorial analysis. For the comparision of bacterial activity in the two fractions, data obtained without regard to sampling times were subjected to a 2 (species) $\times 3$ (feeds) $\times 2$ (bacterial fractions) factorial analysis, since statistical analysis of each bacterial fraction showed no differences between sampling times in all parameters measured.

\section{Results and Discussion}

Feed intakes per $100 \mathrm{~kg}$ body weight of buffaloes were $1.0,1.3$ and $2.0 \mathrm{~kg}$, respectively, on rice straw, timothy hay and alfalfa hay cubes, and those of cattle 
$0.9,1.1$ and $2.5 \mathrm{~kg}$, respectively. Both species maintained their body weights when they were fed timothy hay, but cattle and buffaloes lost about 0.5 and $2.8 \%$, respectively, on the feeding with rice straw, and increased 6.8 and $3.7 \%$, respectively, on alfalfa hay cubes. Juging from overall evaluation based on the results of the feed intake and the change of body weight in addition to the chemical composition of roughages (Table 1), alfalfa hay cubes were best in quality among the three roughages employed, then, in decreasing order, timothy hay and rice straw.

Buffaloes and Cattle

Several investigators have reported that buffaloes were greater in number of rumen bacteria than cattle ${ }^{4,5}$. A higher concentration of rumen bacteria may promote their association with plant materials. As expected, concentration of bacteria indicated by

Table 1. Chemical composition of roughages

\begin{tabular}{lcccccr}
\hline Feed & DM & CP & EE & CF & NFE & Ash \\
\hline & $\%$ & & & & $\% / D M$ & \\
Rice straw & 89.4 & 3.6 & 1.4 & 28.9 & 51.7 & 14.4 \\
Timothy hay & 88.9 & 10.1 & 1.4 & 30.7 & 52.5 & 5.3 \\
Alfalfa hay cubes & 96.2 & 11.8 & 1.3 & 28.1 & 48.8 & 10.0 \\
\hline
\end{tabular}

DM: dry matter, $\mathrm{CP}$ : crude protein, EE: ether extract, $\mathrm{CF}$ : crude fiber, NFE: nitrogen free extract.

Table 2. Cellulase activity, concentration of 2,6-diaminopimelic acid (DAP) and specific activity of solid-associated bacteria $(\mathrm{SAB})$ in the rumen digesta of buffaloes and cattle

\begin{tabular}{|c|c|c|c|c|c|c|c|c|}
\hline \multirow{2}{*}{$\begin{array}{l}\text { Feed: } \\
\text { Animal: }\end{array}$} & \multicolumn{2}{|c|}{ rice straw } & \multicolumn{2}{|c|}{ timothy hay } & \multicolumn{2}{|c|}{ alfalfa hay cubes } & \multirow[t]{2}{*}{ Signif. } & \multirow[t]{2}{*}{ factor $^{c}$ s. ed. } \\
\hline & cattle & buffaloes & cattle & buffaloes & cattle & buffaloes & & \\
\hline Time (h) & & Cellulase & ctivity ${ }^{\mathrm{a}}$ & & & & & \\
\hline 0 & 6.7 & 9.2 & 17.7 & 9.5 & 15.0 & 21.4 & & \\
\hline 2 & 7.9 & 9.4 & 18.0 & 16.0 & 15.4 & 20.5 & & \\
\hline 4 & 7.6 & 9.4 & 21.7 & 13.0 & 18.5 & 19.4 & & \\
\hline \multirow[t]{2}{*}{ mean } & 7.4 & 9.3 & 19.1 & 12.8 & 16.3 & 20.9 & $\mathbf{F} * *$ & 4.79 \\
\hline & \multicolumn{4}{|c|}{ Concentration of $\mathrm{DAP}^{\mathrm{b})}$} & & & & \\
\hline 0 & 0.39 & 0.62 & 0.81 & 0.50 & 1.40 & 1.69 & & \\
\hline 2 & 0.39 & 0.69 & 1.00 & 0.93 & 1.20 & 1.56 & & \\
\hline 4 & 0.43 & 0.65 & 0.70 & 0.77 & 0.87 & 1.94 & & \\
\hline \multirow[t]{2}{*}{ mean } & 0.40 & 0.66 & 0.84 & 0.74 & 1.15 & 1.73 & $\mathbf{A}^{*}, \mathbf{F}^{*}$ & 0.23 \\
\hline & \multicolumn{6}{|c|}{ Specific activity (cellulase activity/DAP) } & & \\
\hline 0 & 15.7 & 12.4 & 23.6 & 16.9 & 13.5 & 13.4 & & \\
\hline 2 & 17.9 & 12.9 & 19.7 & 16.9 & 16.5 & 13.3 & & \\
\hline 4 & 15.5 & 13.2 & 32.4 & 17.0 & 18.5 & 12.2 & & \\
\hline mean & 16.4 & 12.6 & 25.3 & 16.9 & 16.2 & 13.0 & $A^{*}, F^{*}$ & 4.15 \\
\hline
\end{tabular}

a: cellulase activity was expressed as glucose mg. $\times 10^{2} / 1 \mathrm{ml}$ of reaction mixture. b: $2,6-$ diaminopimelic acid $\mathrm{mg} / 100 \mathrm{ml}$ of enzyme solution. $\mathrm{c}$ : significant factor; A-animal, F-feed (*; $\mathrm{P}<0.05, * * ; \quad \mathrm{P}<0.01)$. $\mathrm{d}$ : standard error of the error mean square in analysis of variance. 
DAP in SAB was significantly higher in buffaloes than in cattle when they were fed rice straw or alfalfa hay cubes (Table 2). When they were fed timothy hay, however, no difference between species was found in the DAP concentration (Table 2). This exception implied involvement of other factors affecting association of rumen bacteria with plant particles in addition to bacterial concentration, for instance, susceptibility of plant cell walls to attack of bacteria' ${ }^{9)}$ or morphological differences between species of bacteria on modes of attack to various cellulosic substrates ${ }^{10}$.

Our previous paper demonstrated that the proportion of cellulolytic bacteria to the total in the whole rumen digesta of buffaloes is almost the same as that of cattle ${ }^{4}$. The composition of species of cellulolytic bacteria in buffaloes was also similar to that in cattle ${ }^{11}$. It was expected, therefore, that the absolute amount of cellulolytic bacteria associated with solid fraction was greater in buffaloes than in cattle, since buffaloes were higher in bacterial concentration in the rumen than cattle ${ }^{4,5}$. However, cellulase activity in SAB was not significantly different between species, although buffaloes were higher in DAP concentration than cattle (Table 2). Consequently, specific activity of cellulase in SAB was significantly lower in buffaloes than in cattle (Table 2). The lower specific activity in buffaloes may probably be due to attachment of more non-cellulolytic bacteria involved in SAB, rather than that of less cellulolytic bacteria. These results suggest that the number of total bacteria adhered to plant particles increases under a higher bacterial concentration but the number of cellulolytic bacteria involved in them is not necessarily increased under this condition.

The DAP concentration, cellulase activity and specific activity in LAB were signi-

Table 3. Cellulase activity, concentration of 2,6-diaminopimelic acid (DAP) and specific activity of liquid-associated bacteria (LAB) in the rumen digesta of buffaloes and cattle



a)b)c)d): See the footnotes of Table 2 . 
ficantly higher in buffaloes than in cattle when they were fed either rice straw or timothy hay but not different between species when they were fed alfalfa hay cubes (Table 3). Consequently, interactions (animal $\times$ feed) were significantly different in those three parameters (Table 3). These results showed that concentration of bacteria and cellulolytic activity in the liquid fraction of cattle increased with quality of roughage, whereas those of buffaloes remained high whichever roughage they were fed. The results obtained in $\mathrm{LAB}$ in buffaloes may be ascribed to a high bacterial concentration in their rumen, because it seems possible that a high concentration of rumen bacteria restricts further bacterial growth in the liquid fraction via mechanisms analogous to a feedback inhibition. ICHHPONANI et al. ${ }^{12)}$ reported a greater difference in cellulose digestibility between the species with nylon bag technique when they were fed only wheat straw than when they were fed equal parts of wheat straw and berseem (Tribolium alexandrium). The findings obtained by this technique coincided with the result of the present experiment, in which it appeared that bigger differences between species in concentration of bacteria or cellulolytic activity in the liquid fraction of digesta were caused by feeding with lower quality roughages than with higher quality.

\section{Liquid-and Solid-Associated Bacteria in the Rumen}

In the present paper, mixed bacteria involved in either the solid or the liquid fraction of digesta may be loosely defined, because of mechanical separation by differential centrifugation. Nevertheless, comparsion of cellulolytic activity in the two fractions was attempted, since little or no regard had been given to the location of enzyme activities in various parts of the heterogenous fermentation performed in the rumen. Concentrations of DAP in both species were lower in SAB (Table 2) than in LAB (Table 3). Cellulase activity and specific activity, however, were much higher in SAB (Table 2) than in LAB (Table 3) for all roughages used. These results showed consistently higher cellulolytic activity in $\mathrm{SAB}$ than in LAB, even though it was considered that $\mathrm{SAB}$ fraction might contain a little cellulase activity originated from some protozoa ${ }^{13)}$. CzERKAWSKI and BRECKENRIDGE ${ }^{14)}$, working with a continuous artificial rumen, defined three fractions of digesta (a free liquid phase, a liquid associated with solid phase and a solid phase) and showed considerable differences in some enzyme activities in each fraction. These evidences suggested different metabolic activity between those bacterial fractions. It is still unclear, however, what relations exist between those compartments of rumen microorganisms. Some investigators $\left.{ }^{9}, 10,16\right)$ observed attack of cellulolytic bacteria with adhering to plant cell walls and placed an emphasis on adhension of bacteria to insoluble substrates such as cellulose. More regard should be paid to activity of cellulolytic bacteria associated with plant materials to elucidate the cellulose digestion in the rumen.

\section{References}

1) Ponnappa, C. G., Mo Noor Uddin and G. V. Raghavan, Indian J. Anim. Sci., 41: 1026-1031. 1971. 


\section{Cellulase Activities in Buffaloes and Cattle}

2) Sebastian, L., V. D. Mudgal and P. G. Nair, J. Anim. Sci., 30: 253-256. 1970.

3) Ichikawa, T. and H. Homma, Proc, Asian-Aust. Association of Anim. Product 2nd Congress. 1982. (in press)

4) Homma, H. and T. Ichikawa, Jpn. J. Zootech. Sci., 54:690-696, 1983.

5) PANT, H. C. and A. Roy, Indian J. Anim. Sci., 40:600-609. 1970.

6) Merry, R. J. and A. B. McAllan, Br. J. Nutr., 50: 701-709. 1983.

7) Broderich, G. A. and D. B. Richer, J, Anim. Sci., 57: suppl. 1. 425. 1983.

8) Association of Official Agricultural Chemist, Official methods of analysis. 11th ed. A. O.A. C., Washington, D. C. 1970.

9) Akin, D.E., Appl. Environ. Microbiol. 31: 562-568. 1973.

10) Dinsdale, D., E. J. Morris and J.S. D. Bacon, Appl. Environ. Microbiol. 36: 160-168. 1978.

11) Sinha, R. N. and B. Ranganathan, J. Appl. Bacteriol. 54. 1-6. 1983.

12) Ichrponani, J. S., G. S. Makkar, G. S. Sidhu and A. L. Moxon, J. Anim. Sci., 21 : 1001. 1962. (abstract).

13) Yoder, R. D., A. Trenkle and W. Burroughs, J. Anim. Sci. 25: 609-612. 1966.

14) CzerisapskI, J. W. and G. Breckenridge, Br. J. Nutr. 47: 331-348. 1982.

15) Patterson, H., R. Irvin, J. W. Costerton and K. J. Cheng, J. Bacteriol. 122: 278-287. 1975.

\section{水牛と牛のルーメンに抢ける飼料付着菌上 \\ 浮遊菌のセルラーゼ活性}

本 間 秀 弥

筑波大学農林学采, 茨城県桜村 305

水牛绀牛よりむルーメン細菌滥度が高いことが前報で 明らかになった，气こで，細菌濃度の相違がルーメン 内の飼料付着菌と浮遊菌の濃度や，それらのセルラーゼ 活性に及ぼす影響について調べた。水牛と牛に品質の異 なる三つの粗飼料（稲ワラ，チモシ一乾草、アルファル ファヘイキェーブ)をそれぞ机独て蚫食させ,ルーメン 液を採食後 $0 ， 2 ４$ 時問に採取した，それを直ちに遠心 分群 $(600 \times \mathrm{g})$ 乙て固型物区（飼料付着菌）上液区（浮 遊菌)に分け，両区の細菌濃度 ( 2,6 -ジアミノピメリ ン酸）上セルラーゼ活性（基筫：カルボキシメチルセル ロース）を測定した。

飼料付着菌の濃度社水牛の力が牛よりも高かったしし
かし，その細菌の七ルラービ活珄には有意差がなく、し たがって，比活性（セルラ一セ活性：細菌浱度）は水牛 の方が牛上り低かったこのことから，細菌濃度が高い ことで，細菌の飼料付着量は增加するが，七ルロース分 解菌の付着は必ずしも增加しないことが示唆された，浮

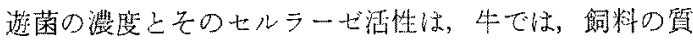
の向上と共に增加したが，水牛ではどの飼料でも高か。 た.

飼料付着菌と浮游菌の比較ては, 前者が後者上り細菌 浱度が低かったが，七ルラーゼ活性と比活性は非常に高 $か っ た$.

日蓄会報, $57(4): 336-341,1986$ 